International Journal of Zoological Investigations

Contents available at Journals Home Page: www.ijzi.net

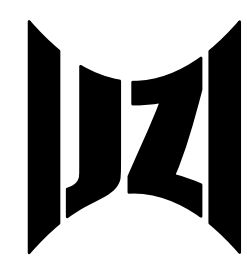

ISSN: 2454-3055

\title{
Relative Abundance and Distribution of Bird Species During Lockdown Period in Mysuru City, Karnataka, India
}

\author{
Chethan B. K. and Suchitra G. ${ }^{*}$ \\ Department of Zoology, Maharani's Science College for Women, Mysuru-570005, Karnataka, India \\ ${ }^{*}$ Corresponding Author
}

Received: $5^{\text {th }}$ June, 2020

Accepted: $30^{\text {th }}$ June, 2020

Published online: $6^{\text {th }}$ July, 2020

https://doi.org/10.33745/ijzi.2020.v06i02.003

\begin{abstract}
Lockdown period by COVID-19 is one of the important time for avifauna with less human disturbances. The relative abundance and distribution of bird species in Mysuru city during lockdown period was assessed. Line and point transect method were followed in 4 different study areas of Devaraja Mohalla, Gangothri, Bogadhi and Srirampura localities of Mysuru city. Relative abundance and their percentage of occurrence were calculated. Total of 3400 birds of 20 families were recorded, the avifauna of study areas is dominated by insectivorous birds. The relative abundance of Devaraja Mohalla showed maximum number, while least in Bogadhi area. Study showed that avifauna has helped by the lockdown period with higher relative abundance and performing its social behavior.
\end{abstract}

Keywords: Relative abundance, Mysuru city, Bird species, Avifauna

Citation: Chethan B.K. and Suchitra G.: Relative abundance and distribution of bird species during lockdown period in Mysuru City, Karnataka, India. Intern. J. Zool. Invest. 6 (2): 240-245, 2020.

https://doi.org/10.33745/ijzi.2020.v06i02.003

\section{Introduction}

Mysuru city have an excellent landscape for several resident and migratory species of birds. There are detailed bird documentations since 1940's. Salim Ali in his historical landmark survey of Mysore state (Ali and Whistler, 1942 a, b; 1943 a, b) covered 343 species from Mysore state (earlier it was Mysore state; as now Mysuru District) characterized by passerines and nonpasserine avifauna. The present modern field ornithologist and amateur bird watchers organization have contributed significantly in adding many bird species into the checklist. Recently, 407 species of birds are enlisted as part of bird count by several bird survey groups from Mysuru area (ebird.com). 
Birds are among the best indicators of environmental changes. Birds are being eyecatching and sensitive towards environmental change and are most suitable biological indicators for monitoring the ecosystem health (Gregory et al., 2001). Birds are often common denizens of the ecosystem and they have been considered as an indicator species of inhabited areas (Blair, 1999). However, human anthropogenic activities have greater impact on distribution and abundance of avian fauna. Several studies reported that human disturbance could affect reproduction and even normal social behaviour (Summers et al., 2011; Dutta, 2017). Birds are even more disrupted by their noise and air pollution made by human activities. Research studies are also evident that human made noise pollution has impact on bird habitat and direct influence on their ability to communicate and response its territory. Interestingly, due to lockdown by COVID-19 there is less interference of human beings with reduced noise and air pollution creating favorable environment for avifauna. In the present study the impact of lockdown on bird abundance and its distribution are assessed to understand the reduced human disturbance on birds. This study would also be the baseline for further studies on bird species distribution and its abundance in Mysuru city.

\section{Materials and Methods}

Bird species and their relative abundance are recorded in 4 different study area of Mysuru city, keeping in view of occurrence of large avifauna in 4 regions such as Devaraja Mohalla, Gangothri, Bhogadi and Srirampura (Fig. 1). In this study, 15 sites in each region are selected as count points. Thus 60 count point station at $100 \mathrm{~m}$ intervals were established. Line transect method were followed to study the birds count. Data was gathered through transect walks from one count point to another for the opportunistic sightings of birds.

Bird survey was done in all 4 regions during the COVID-19 lockdown period from March 5, 2020 to May 30, 2020. Birds were counted at each station in early morning from 7.00 to $11.00 \mathrm{~h}$ for 10 minute following method of Gutzwiller (1991), Jimence (2000) and Lee and Marsden (2008). The birds were counted by visiting 4 alternative days of intervals for each region in order to obtain reliable estimate and reduce bias. During each count, all bird species and individual bird calls were identified and recorded. Photography was done by using binoculars ( $8 \times 42$ ) and Nikon D5600 SLR camera with 70-300 mm Zoom lens. Captured photos were identified using bird's field guide books of Ali and Ripley (1987) and Grimmelt et al. (2011). The relative abundance (\%) of bird species were estimated according to Gutzwiller (1991) following expression of n/ N X 100, where ' $n$ ' is the number of a particular bird species and ' $\mathrm{N}$ ' is the total observations detected for all bird species.

\section{Results}

Total 3400 birds of 20 families have been recorded during the study period. Out of them two families Accipitridae and Muscicapidae $(n=3)$ represented more than the other families (Table 1). Among 4 study areas, Devaraja Mohalla area is observed with more bird species, while Bogadhi area was least. Five maximum bird species were recorded in all the four study areas. Common mynaAcridotheres tristis (7.82\%), Rose-ring parakeet- Psittacula krameri (4.0\%), House crow - Corvus splendens (3.8\%), Rock dove Columba livia (3.7\%) and Red whiskered 
bulbul- Pycnonotus jocosus (2.7\%) shows the highest relative abundance in all the 4 study areas. On contrary, White cheeked barbetMegalaima viridis (1.5\%) and Rosy starlingPastor roseus were least abundant from one study area to other. Three species Oriental white ibis- Threskiornis melanocephalus, Black rumped flameback- Dinopium benghalense and Grey Frankolin- Frankolinus pondeceranus were not recorded in Devaraja Mohalla area.

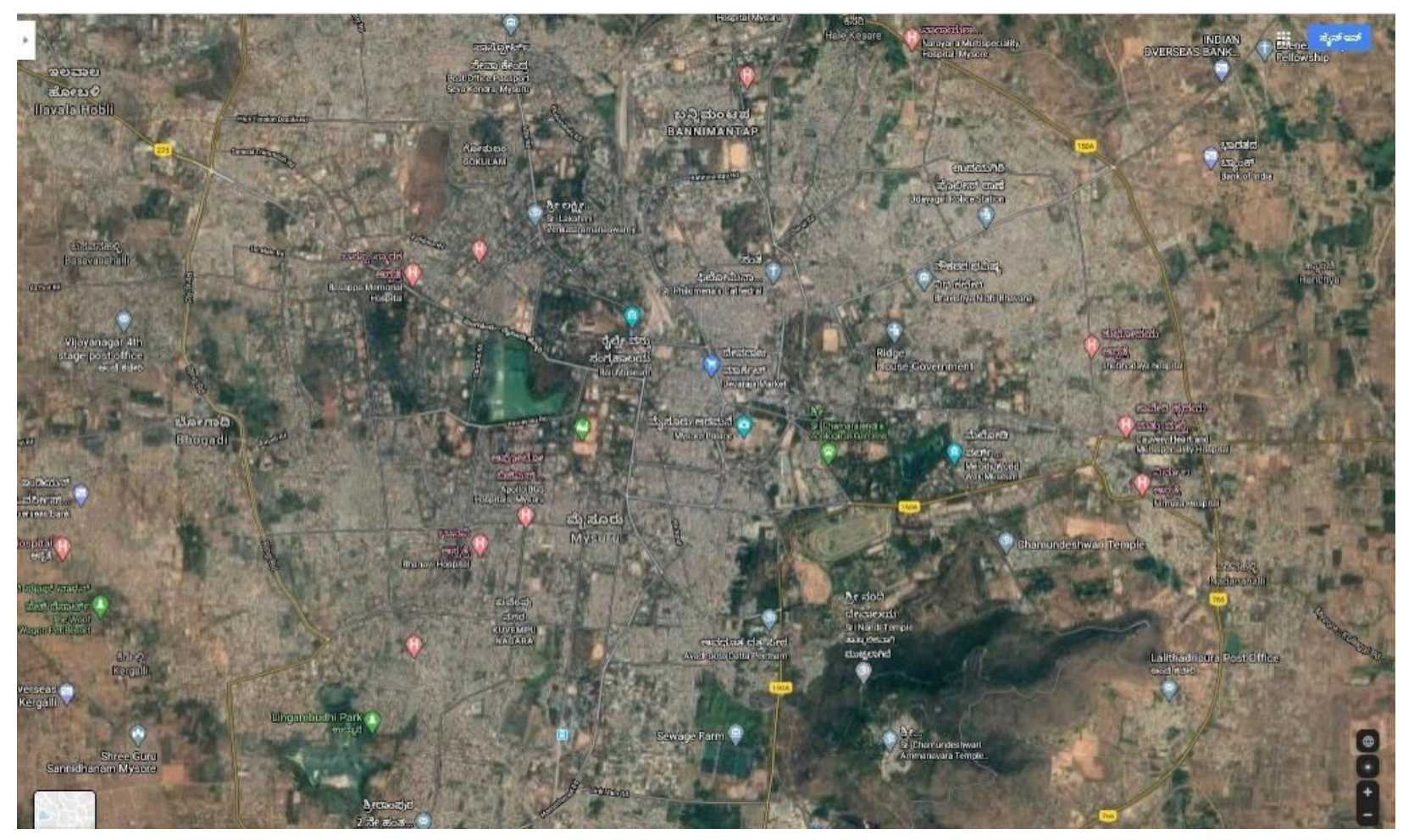

Fig. 1: Google earth image showing habitats of the study area.

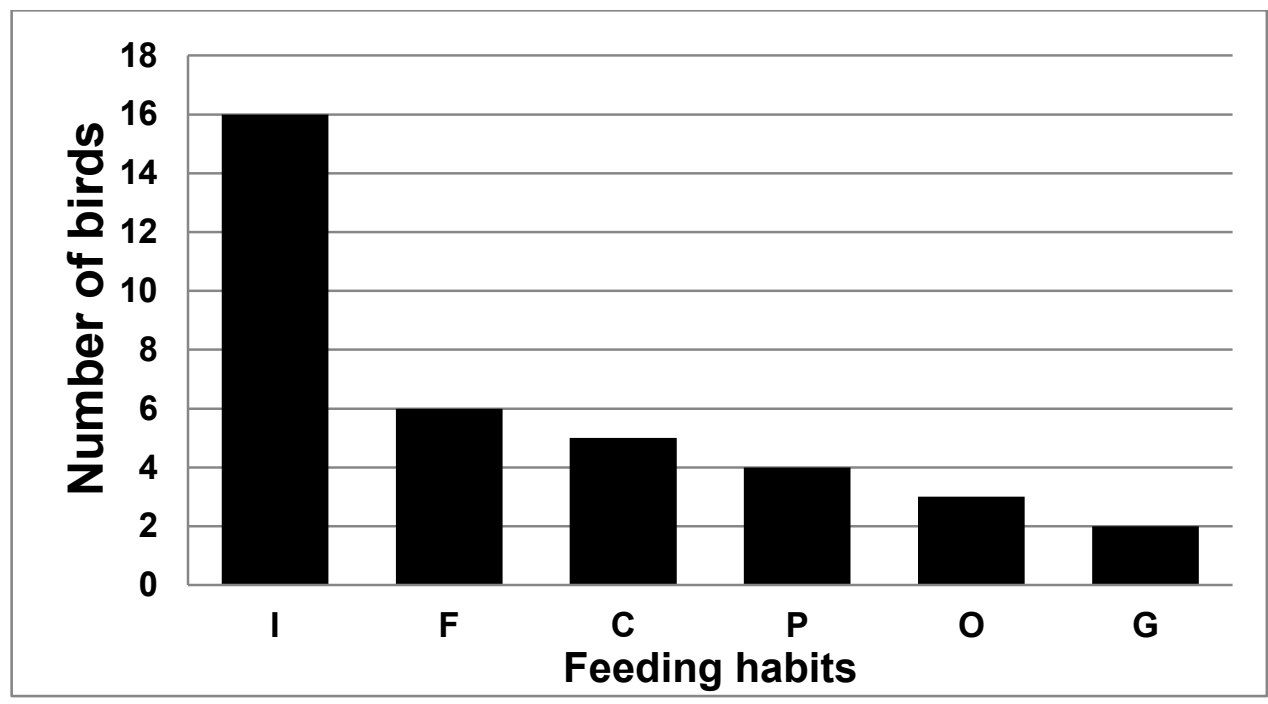

Fig. 2: Number of birds according to their feeding habits in the study area. 
Table 1: Relative abundance and percentage of occurrence in various families of bird species in the study areas

\begin{tabular}{|c|c|c|c|c|c|c|c|c|c|c|c|}
\hline \multirow{3}{*}{ Family } & \multirow{3}{*}{$\begin{array}{l}\text { Scientific } \\
\text { name }\end{array}$} & \multirow{3}{*}{$\begin{array}{l}\text { Common } \\
\text { name }\end{array}$} & \multicolumn{6}{|c|}{ Number observation with study areas } & & & \multirow{3}{*}{$\begin{array}{l}\text { Food } \\
\text { Habitas }\end{array}$} \\
\hline & & & \multicolumn{2}{|c|}{ Devaraja Mohalla } & \multicolumn{2}{|c|}{ Gangothri } & \multicolumn{2}{|c|}{ Bogadhi } & \multicolumn{2}{|c|}{ Srirampura } & \\
\hline & & & Observation & $\begin{array}{c}\% \text { of all } \\
\text { detection }\end{array}$ & observation & $\begin{array}{c}\% \text { of all } \\
\text { detection }\end{array}$ & observation & $\begin{array}{c}\% \text { of all } \\
\text { detection }\end{array}$ & observation & $\begin{array}{c}\text { \% of all } \\
\text { detection }\end{array}$ & \\
\hline Sturnidae & $\begin{array}{l}\text { Acridotheres } \\
\text { tristis }\end{array}$ & Common myna & 266 & 7.82 & 174 & 5.11 & 120 & 3.52 & 112 & 3.29 & $\mathrm{O}$ \\
\hline Psittaculidae & $\begin{array}{l}\text { Psittacula } \\
\text { krameri }\end{array}$ & $\begin{array}{l}\text { Rose-ring } \\
\text { parakeet }\end{array}$ & 136 & 4.00 & 98 & 2.88 & 74 & 2.17 & 65 & 1.91 & $F, G$ \\
\hline Corvidae & $\begin{array}{l}\text { Corvus } \\
\text { splendens }\end{array}$ & House crow & 131 & 3.85 & 89 & 2.61 & 128 & 3.76 & 83 & 2.44 & $\mathrm{O}$ \\
\hline Columbidae & Columba livia & Rock dove & 128 & 3.76 & 65 & 1.91 & 82 & 2.41 & 17 & 0.50 & $\mathrm{G}, \mathrm{F}$ \\
\hline Pycnonotidae & $\begin{array}{l}\text { Pycnonotus } \\
\text { jocosus }\end{array}$ & $\begin{array}{l}\text { Red-whiskered } \\
\text { bulbul }\end{array}$ & 93 & 2.73 & 76 & 2.23 & 89 & 2.61 & 51 & 1.50 & 1 \\
\hline Megalaimidae & $\begin{array}{l}\text { Megalaima } \\
\text { viridis }\end{array}$ & $\begin{array}{l}\text { White-cheeked } \\
\text { barbet }\end{array}$ & 54 & 1.58 & 25 & 0.73 & 21 & 0.61 & 21 & 0.61 & $\mathrm{~F}$ \\
\hline Sturnidae & Pastor roseus & Rosy starlings & 42 & 1.23 & 00 & 0.00 & 00 & 0.00 & 63 & 1.85 & C \\
\hline Cisticolidae & Prinia socialis & Ashy prinia & 32 & 0.94 & 27 & 0.79 & 30 & 0.88 & 24 & 0.70 & I \\
\hline Bucerotidae & $\begin{array}{l}\text { Ocyceros } \\
\text { birostris }\end{array}$ & $\begin{array}{l}\text { Indian grey } \\
\text { hornbill }\end{array}$ & 26 & 0.76 & 12 & 0.35 & 17 & 0.50 & 09 & 0.26 & I \\
\hline Threskironithidae & $\begin{array}{l}\text { Pseudibis } \\
\text { papillosa }\end{array}$ & Red-naped Ibis & 26 & 0.76 & 13 & 0.38 & 08 & 0.23 & 02 & 0.05 & $P, I$ \\
\hline Accipitridae & Milvus migrans & Black kite & 20 & 0.58 & 13 & 0.38 & 11 & 0.32 & 37 & 1.08 & C \\
\hline Nectariniidae & $\begin{array}{l}\text { Leptocoma } \\
\text { zeylonica }\end{array}$ & $\begin{array}{l}\text { Purple-rumped } \\
\text { sunbird }\end{array}$ & 19 & 0.55 & 15 & 0.44 & 10 & 0.29 & 16 & 0.47 & 1 \\
\hline Strigidae & Athene brama & Spotted owlet & 18 & 0.52 & 02 & 0.05 & 05 & 0.14 & 01 & 0.02 & C \\
\hline Ardeidae & Bubulcus ibis & Cattle egret & 15 & 0.44 & 25 & 0.73 & 28 & 0.82 & 48 & 1.41 & $P$ \\
\hline Cuculidae & $\begin{array}{l}\text { Eudynamys } \\
\text { scolopaceus }\end{array}$ & Asian koel & 13 & 0.38 & 07 & 0.20 & 04 & 0.11 & 06 & 0.17 & $\mathrm{~F}$ \\
\hline Cuculidae & $\begin{array}{l}\text { Centropus } \\
\text { sinensis }\end{array}$ & Greater coucal & 11 & 0.32 & 09 & 0.26 & 08 & 0.23 & 07 & 0.20 & I \\
\hline Muscicapidae & $\begin{array}{l}\text { Copsychus } \\
\text { saularis }\end{array}$ & $\begin{array}{l}\text { Oriental } \\
\text { magpie robin }\end{array}$ & 09 & 0.26 & 02 & 0.05 & 04 & 0.11 & 02 & 0.05 & I \\
\hline Accipitridae & Haliastur indus & Brahminy kite & 08 & 0.23 & 11 & 0.32 & 05 & 0.14 & 18 & 0.52 & C \\
\hline Columbidae & $\begin{array}{l}\text { Streptopelia } \\
\text { chinenis }\end{array}$ & Spotted dove & 08 & 0.23 & 04 & 0.11 & 05 & 0.14 & 04 & 0.11 & C \\
\hline Accipitridae & Accipiter badius & Shikra & 05 & 0.14 & 01 & 0.02 & 01 & 0.02 & 06 & 0.17 & C \\
\hline Muscicapidae & $\begin{array}{l}\text { Cyornis } \\
\text { tickelliae }\end{array}$ & $\begin{array}{l}\text { Tickell's blue } \\
\text { flycatcher }\end{array}$ & 04 & 0.11 & 05 & 0.14 & 08 & 0.23 & 02 & 0.05 & 1 \\
\hline Muscicapidae & $\begin{array}{l}\text { Saxicoloides } \\
\text { fulicatus }\end{array}$ & Indian robin & 04 & 0.11 & 01 & 0.02 & 02 & 0.05 & 15 & 0.44 & 1 \\
\hline Alcedinidae & $\begin{array}{l}\text { Halcyon } \\
\text { smyrnensis }\end{array}$ & $\begin{array}{l}\text { White throated } \\
\text { kingfisher }\end{array}$ & 03 & 0.08 & 06 & 0.17 & 07 & 0.20 & 04 & 0.11 & $P, I$ \\
\hline Charadriidae & Vanellus indicus & $\begin{array}{l}\text { Red-wattled } \\
\text { lapwing }\end{array}$ & 02 & 0.05 & 25 & 0.73 & 12 & 0.35 & 38 & 1.11 & I \\
\hline Leiothrichidae & $\begin{array}{l}\text { Turdoides } \\
\text { affinis }\end{array}$ & $\begin{array}{l}\text { Yellow-billed } \\
\text { babbler }\end{array}$ & 02 & 0.05 & 15 & 0.44 & 5 & 0.14 & 17 & 0.50 & 1 \\
\hline Rhipiduridae & $\begin{array}{l}\text { Rhipidura } \\
\text { albicollis }\end{array}$ & $\begin{array}{l}\text { White throated } \\
\text { fantail }\end{array}$ & 02 & 0.05 & 06 & 0.17 & 10 & 0.29 & 08 & 0.23 & 1 \\
\hline Pycnonotidae & $\begin{array}{l}\text { Pycnonotus } \\
\text { cafer }\end{array}$ & $\begin{array}{l}\text { Red-vented } \\
\text { bulbul }\end{array}$ & 02 & 0.05 & 05 & 0.14 & 03 & 0.08 & 37 & 1.08 & $\mathrm{~F}$ \\
\hline Burhinidae & $\begin{array}{l}\text { Burhinus } \\
\text { indicus }\end{array}$ & $\begin{array}{l}\text { Indian thick } \\
\text { knee }\end{array}$ & 02 & 0.05 & 01 & 0.02 & 01 & 0.02 & 02 & 0.05 & I \\
\hline Phasianidae & Pavo cristatus & Peafowl & 01 & 0.02 & 08 & 0.23 & 14 & 0.41 & 03 & 0.08 & $\mathrm{O}$ \\
\hline Threskiornithidae & $\begin{array}{l}\text { Threskiornis } \\
\text { melanocephalus }\end{array}$ & $\begin{array}{l}\text { Oriental white } \\
\text { lbis }\end{array}$ & 00 & 0.00 & 94 & 2.76 & 05 & 0.14 & 14 & 0.41 & $P, I$ \\
\hline Picidae & $\begin{array}{l}\text { Dinopium } \\
\text { benghalense }\end{array}$ & $\begin{array}{l}\text { Black rumped } \\
\text { flame back }\end{array}$ & 00 & 0.00 & 05 & 0.14 & 03 & 0.08 & 08 & 0.23 & 1 \\
\hline \multirow[t]{2}{*}{ Phasianidae } & $\begin{array}{l}\text { Frankolinus } \\
\text { pondeceranus }\end{array}$ & Grey Frankolin & 00 & 0.00 & 04 & 0.11 & 03 & 0.08 & 12 & 0.35 & $\mathrm{~F}$ \\
\hline & Total & & 1082 & & 843 & & 723 & & 752 & & \\
\hline
\end{tabular}

C- carnivorous, F- frugivorous, G- grainivorous, I- insectivorous, O- omnivorous, P- piscivorous 
Furthermore, Oriental headed ibisThreskiornis melanocephalus were near threatened and other rest bird species were least concerned in IUCN red list 2015. However, based on the food habits, it is noticed that the avifauna of these study area is dominated by insectivorous (16 species) followed by Frugivorous, carnivorous, piscivorous, omnivorous and granivorous birds with 6, 5,4,3,2 species, respectively (Fig. 2).

\section{Discussion}

In all 4 study areas, the highest relative abundance of 5 bird species Common myna, Rose-ring parakeet, Rock dove, House crow and Red whisked bulbul were gathering together due to their coexistence of species. The possible reasons for increased number of birds in city limits were due to stronger association with human population, their dependence primarily on left-over food disposed in open area around the residence, grain-shops and restaurants. The above observations were in consistent with Mukherjee et al. (2002). The emerging roadside vegetation also helped them in getting food along with their daily activities of roosting, foraging and nesting behaviours for these bird species.

Insectivorous birds Ashy prinia, Purple sunbird, Red whiskered bulbul, Rosy starlings and Indian Grey hornbill were relatively in higher per cent of abundance in all study areas. It is apparent from Fig. 2 that the avifauna of study area is dominated by insectivorous birds. The possible reasons of their higher density are by the substantial increase in insect population over the season. It was also observed that the lesser human disturbance with absence of noise pollution helped these bird song signals connecting many individual species resulting in communication network and their gathering.

White ibis, Brahminy kite, Cattle egret, Red naped ibis and White throated kingfisher have showed varying degree of occurrence in different study area. This is due to the preference of water resources to look for their food. It was observed that the availability of food resources in waste water running along the city and marsh pools are best locations for these birds. This result indicated that the relationship between birds and habitats influence on the distribution and diversity of avian species. These birds also preferred to forage in less human interference avoid disturbance made by various human activities.

Blair (1996) and Salahudeen et al. (2013) suggested that the human disturbance negatively affect the richness and diversity of birds. We had the same observation that the Peafowls, Grey francolin, Greater coucal and spotted owlet occurred in groups in places of least human disturbances. The lockdown period has undoubtedly helped them gathering in large numbers in their habitats. In context to human disturbance, Black rumped flame black, Rosy starlings, Indian thick knee and Indian robin which were not found on one study area have made their appearance in other areas, showing interesting spatial distribution patterns which mainly depends on the microclimatic conditions with their habitats. Consequently, birds are often been correlated with their habitats (Seymour et al., 2008). Further, systematic investigation is required to understand the fine-scale relationship between birds and their habitat. 


\section{Conclusion}

Lockdown period is considered as important time for bird species with lesser human activities and noise pollution. Bird species not only add aesthetic value to our life but also help in agriculture and in maintaining healthy ecological balance. The results revealed that lockdown period has benefited bird species with greater relative abundance, gathering together, performing roasting and foraging behaviours.

\section{Acknowledgement}

Authors are grateful to Head, Department of Zoology, Maharani's Science College for Women for providing the laboratory facilities.

\section{References}

Ali S and Ripley SD. (1987) A compact Handbook of the Birds of India and Pakistan, Second Edition. Oxford University press, Mumbai.

Ali S and Whistler H. (1942 a) The birds of Mysore. Part I. Journal of the Bombay Natural History Society. 43:130-147.

Ali S and Whistler H. (1942 b) The birds of Mysore. Part II. J. Bombay Nat. History Soc. 43: 318-341.

Ali S and Whistler H. (1943 a) The birds of Mysore. Part III. J. Bombay Nat. History Soc. 43: 573-595.

Ali S and Whistler H. (1943 b) The birds of Mysore. Part II. J. Bombay Nat. History Soc. 44: 9-26.

Blair RB. (1996) Land use and avian species diversity along an urban gradient. Ecol. Appl. 6: 506-519.
Dutta H. (2017) Insight into the impact of four current environmental problems on flying birds. Energy Ecol. Environ. 2: 329-349.

e-bird.com: http://www.ebird.org/India > Mysore city Bird Atlas.

Grimmelt R, Inskipp C and Inskipp T. (2011) Birds of the Indian subcontinent ( $2^{\text {nd }}$ edition), Oxford press.

Gutzwiller J. (1991) Estimating winter species richness with unlimited-distance point counts. The Auk 108: 853-862.

Jimenez JE. (2000) Effect of sample size, plot size, and counting time on estimates of avian diversity and abundance in a Chilean rainforest. J. Field Ornithol. 71: 66-87.

Lee DC and Marsen SJ. (2008) Adjusting count period strategies to improve the accuracy of forest bird abundance estimates from point transect distance sampling surveys. Ibis 150: 315-325.

Mukherjee A, Borad CK and Parasharya BM. (2002) A study of the ecological requirements of waterfowl at man-made reservoirs in kheda District, Gujarat, India, with a view towards conservation, management and planning. Zoos' Print J. 17: 775785.

Salahudeen M, Saranya E, Gunasekaran C and Vadivalagan C. (2013) Studies on the abundance and Distributon of birds in three different Habitats of Karur District, South India. J. Entomol. Zool. Stud. 1: 57-63.

Seymour CL and Simmons RE. (2008) "Can severely fragmented patches of riparian vegetation still be important for arid-land bird diversity". J. Arid Environ. 72: 2275-2281.

Summers PD, Cunnington GM and Fahrig L. (2011) Are the negative effects of roads on breeding birds caused by traffic noise. J. Appl. Ecol. 48: 1527-1534. 